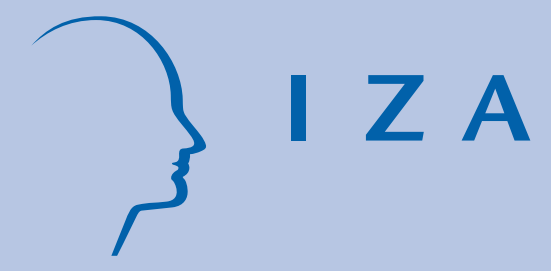

IZA Policy Paper No. 9

Flexicurity in Belgium:

A Proposal Based on Economic Principles

Bart Cockx

Bruno Van der Linden

May 2009 


\title{
Flexicurity in Belgium: A Proposal Based on Economic Principles
}

\author{
Bart Cockx \\ Ghent University, Université catholique de Louvain, \\ CESifo and IZA
}

Bruno Van der Linden

Université catholique de Louvain

and IZA

Policy Paper No. 9

May 2009

IZA

P.O. Box 7240

53072 Bonn

Germany

Phone: +49-228-3894-0

Fax: +49-228-3894-180

E-mail: iza@iza.org

The IZA Policy Paper Series publishes work by IZA staff and network members with immediate relevance for policymakers. Any opinions and views on policy expressed are those of the author(s) and not necessarily those of IZA.

The papers often represent preliminary work and are circulated to encourage discussion. Citation of such a paper should account for its provisional character. A revised version may be available directly from the corresponding author. 
IZA Policy Paper No. 9

May 2009

\section{ABSTRACT}

\section{Flexicurity in Belgium: A Proposal Based on Economic Principles ${ }^{*}$}

The current unemployment insurance and employment protection legislation were set up in an economic environment in which relationships between workers and firms were typically long-lasting and stable. The increasing globalisation of the economy and the rapid technological and organisational changes require more flexibility of both workers and firms leading to career paths which are much more volatile both within and between firms. Current institutions must be therefore urgently reformed to reconcile this new need of more flexibility with that of security for workers. The call for "flexicurity" is not new, but there is no unanimity on the corresponding institutional model it implies. Rather than proposing a reform on the basis of existing institutions abroad, we propose a reform that is explicitly guided by economic principles. In a nutshell, we propose to transform the bulk of the advance notice payments by a unique lay-off contribution, independently of the type of worker (blue or whitecollar) and type of contract (temporary or open-ended). A severance payment, less important than the lay-off contribution, is due to cover the psychic cost related to dismissal. In order to make the employer accountable for the costs he imposes on society, the lay-off contribution should be made proportional to the cumulative past earnings since the moment that the worker was hired in the firm. This contribution would be used not only to finance a supplement to the current unemployment benefits, but also, as to make the worker more accountable, to finance active labour market policies for the unemployed. Aside of this scheme, it makes sense to generalise the current scheme of temporary unemployment benefits for blue-collar workers to white-collar workers, but only to the extent that one introduces experience rating in the funding, so that again the employers are made accountable for the social costs that they induce by these temporary lay-offs.

JEL Classification: H11, H21, H23, J65, J68

Keywords: flexicurity, employment protection, unemployment insurance, active labour market policies, optimal design

Corresponding author:

Bart Cockx

Ghent University

Tweekerkenstraat 2

B-9000 Gent

Belgium

E-mail: bart.cockx@ugent.be

\footnotetext{
* We are very grateful for valuable comments received from Pierre Cahuc, Jacques Drèze, Muriel Dejemeppe, Glenn Rayp and Henri Sneessens.
} 
As many others, the current Unemployment insurance (UI) and employment protection legislation (EPL) "institutions" were set up in a economic environment in which relationships between workers and firms were typically long-lasting and stable. The increasing globalisation of the economy and the rapid technological and organisational changes require more flexibility of both workers and firms leading to career paths which are much more volatile both within and between firms. Current institutions must be therefore urgently reformed to reconcile this new need of more flexibility with that of security for workers. The call for "flexicurity" is not new, but there is no unanimity on the corresponding institutional model it implies. ${ }^{4}$ Rather than proposing a reform on the basis of existing institutions abroad, we believe that it is essential to first formulate some explicit principles guiding this reform rooted in economic analysis. Making these principles explicit is a distinctive feature of our approach compared to De Vos and Konings (2007) and Sels (2008). In a second step, after a brief summary of Belgian labour market institutions, we reflect on how to translate these principles to concrete guidelines of reform of the current institutions in Belgium.

\section{General Principles for the Design of Labour Market Institutions}

The Design of Employment Protection

Our starting point is the following citation of Blanchard and Tirole (2004):

Let us begin with a broad principle: Economic agents can be given discretion provided that they bear the cost that their decisions impose on other agents. This 'internalization of externalities' ensures that the decision-maker in question reflects others' preferences and is therefore accountable. For example, it is widely accepted that polluters ought to pay for the social cost of their pollution.

The translation of this broad principle in the matter of employment is that firms ought to pay for the cost they impose on society when they lay workers off. This cost includes the financial cost born by the unemployment insurance (UI) fund and the psychological and other costs born by the dismissed worker. ${ }^{5} .$. (Blanchard and Tirole, 2004, p. 4)

Our starting point is therefore the general principle that firms should pay for the costs that lay-offs impose on society. It's important to note that the financial costs born by the UI fund include the cost of active labour market policies (ALMP) needed to insert the unemployed back into employment. In addition, not mentioned in the citation, the loss of tax payments, required to finance public goods and other transfers than unemployment benefits (UB), is part of the social cost induced by a lay-off.

Blanchard and Tirole $(2003,2004,2008)$ explain nevertheless that, since the real world exhibits a number of imperfections, this general principle requires a refinement. For instance, one of the

\footnotetext{
${ }^{4}$ For a recent discussion on flexicurity from an international perspective, we refer the reader to a special issue on Flexicurity in the CESifo DICE Report, Journal for Institutional Comparison, Volume 6, No. 4, Winter 2008.

${ }^{5}$ Collective layoffs may further impose substantial costs on local communities in a depressed area.
} 
difficulties of the scheme is that the firms can shift the increased cost of lay-off on the worker by refusing to hire disadvantaged workers with high unemployment risk or paying them lower wages. ${ }^{6}$ In addition, financially fragile firms could go broke as a consequence of the increased liability or they could evade their responsibility, notably by delocalisation or by deliberately reducing their capitalisation. As consequence of these and other complications, Blanchard and Tirole conclude that firms should be made only partially responsible for the costs they impose by laying-off their workers. It is, however, impossible with the current knowledge to determine the optimal compensation that firms are due at lay-off.

Even if we cannot determine the optimal degree to which employers should be made responsible for their lay-off decisions, a general principle of incentive pay (the "informativeness principle") dictates that the degree of responsibility should increase to the extent that one can exclude components of the lay-off cost for which the employer cannot be made accountable (Milgrom and Roberts, 1992, p. 219). For instance, lay-offs can be a consequence of external factors that are beyond the control of the individual firm. The fall in aggregate demand, as generated by the recent financial crisis, is a typical example. The degree of responsibility should therefore increase if we could relate the compensation at lay-off to the difference between the lay-off costs induced by the firm and the average lay-off costs in the economy.

Once economic agents are made responsible for their acts, they "can be given discretion". This means that one should not require firms to justify economic lay-offs ${ }^{7}$ in court, as e.g. in France. Judicial procedures cannot be efficient since it is too costly for a judge to gather the relevant information required to determine whether the lay-off is economically justified.

What form should the firm's contribution take? Should it take the form of a lump-sum severance payment to the worker or of a lay-off contribution to the $\mathrm{UI}$ fund that finances a stream of unemployment benefits (UB) and active labour market policies (ALMP's)? Here economic principles provide more clear-cut policy advice (Blanchard and Tirole, 2003, p. 22). Suppose that all compensation would take the form of a lump-sum transfer to the dismissed worker such that it covers the cost of unemployment on average. This is clearly inefficient, since (i) this transfer will be too high if unemployment duration is less than average and too low if it is longer and (ii) job-seekers can only partially influence this length. The UI Agency insures the worker against this unemployment risk. A lump-sum payment is only justified to compensate for the psychic costs of becoming unemployed, unrelated to the cost of being unemployed: this could be e.g. the loss of a familiar work environment, of work relationships,... For most workers, the costs related to the unemployment risk are without doubt much larger than these psychic costs. So, we can conclude that a lay-off contribution is needed in addition to a severance payment, the latter being relatively less important than the former.

Should the compensation be due if the laid-off worker is immediately employed in another firm on a voluntary basis (or voluntarily withdraws from the labour market)? We argue that in that case the firm should only pay the severance payment that compensates for the psychic cost of unemployment and not the contribution to the UI fund, since the latter is no longer needed. It is important to realise

\footnotetext{
${ }^{6}$ This problem can be partially resolved by targeting hiring subsidies to these workers, but it may be complicated to practically implement these without abuse.

${ }^{7}$ Courts should, however, still guard against arbitrary lay-offs.
} 
that such a scheme provides incentives to the firm to finance outplacement services to the extent that this is cheaper than paying the contribution to the UI fund (Cahuc and Kramarz, 2004, p. 162).

Finally, economic principles provide a justification for advance notice of dismissal (Pissarides, 2001). Where severance payments can in principle perfectly insure the worker against job loss, advance notice insures the worker against the risk of not being rehired after lay-off: during this period, the worker can search for a new job without any income loss. This justifies in principle a notice period of, say, a few months. The advance notice of dismissal is, however, costly, since the dismissed worker has no longer an incentive to be as productive as she used to be. That's the reason why employers often prefer the notice period not to be served. If this is the case, it may be more efficient to substitute a system of advance notice of dismissal by an adequate UI, at least to the extent that one can be entitled to it immediately after lay-off.

\section{Efficient Unemployment Insurance}

The UI fund should finance (i) the UB that compensates for the income loss induced by the dismissal; (ii) the cost of remedying the firm-specific human capital that is lost upon lay-off and the loss in general human capital in the course of the unemployment spell. Since job-search effort is imperfectly observed by the administrators of the UI fund, we cannot fully insure the unemployed workers against earnings loss. For, full insurance would drastically reduce the incentive to search for jobs and to accept job offers. Incentives can be provided financially (by a decreasing profile of UB or of a hiring bonus/tax to/on the worker ${ }^{8}$ ) or non-financially (by offering job search training and intermediation services, by imposing job search requirements and/or by verifying the acceptance of suitable job offers).

To compensate for the loss in human capital, the worker should participate in suitable training programmes. If training is too costly, e.g. because the worker is close to retirement age, the worker could receive a wage subsidy to compensate for the lost productivity. Since the social benefits of investment in human capital exceed the private benefits, it may be necessary to offer this training at reduced cost, or even to either subsidise or enforce participation in training.

From the above discussion it is clear that the Unemployment Agency (UA) ${ }^{9}$ has a specific mission. Since the worker underestimates the social value of employment, ${ }^{10}$ the choice of the appropriate allocation of funds between UB and ALMP's cannot be left to the worker. This is the responsibility of the government through the UA. The UA should aim at maximizing the expected lifetime welfare of the unemployed workers given scarce public resources. A complication is that this requires aligning the objective of the employees of the UA to the aforementioned goal. This could partly be resolved by appropriate incentive contracts, but since it is difficult to measure the objective precisely, the design of such incentive contracts is hazardous (see e.g. Cockx, 2000).

\footnotetext{
${ }^{8}$ See Hopenhayn and Nicolini (1997).

${ }^{9}$ By UA we refer to the agency that is responsible for both the payment of UB and the provision of ALMP. In Belgium, the two functions are separated, a federal agency being responsible for the first mentioned service and the regional public employment services (PES) for the second. We discuss the issue of decentralisation in another contribution (Cockx and Van der Linden, 2009).

${ }^{10}$ For, in addition to the private gains, society as a whole has to finance less benefits and collects more taxes.
} 


\title{
2. Guidelines for a Reform of Employment Protection and Unemployment Insurance in Belgium
}

\author{
The Current Institutional Setting in a Nutshell ${ }^{11}$
}

In the current institutional setting essentially two institutions protect workers against job loss: The Unemployment Insurance (UI) and the employment protection regulations (EPL). First, in Belgium employers need not justify the reason of dismissal, ${ }^{12}$ but they must notify workers sufficiently in advance if they want to dismiss a worker. The notice period need not be served if the employer compensates the worker by paying out the wage due in this notice period. This corresponds therefore to a severance payment. In Belgium, the notice period is much higher for white-collar workers than for blue-collars. It also differs according to the collective agreement in the sector, the nature of the contract (open-ended, fixed-term,...) and on whether the worker is serving a trial period or not. Special procedures apply if there is a collective dismissal, i.e. if the employer lays-off a group of workers simultaneously. The timing of the procedure is complex. The employer must in due time inform workers, their unions and the regional public employment service (PES). This implies that the lay-off has to be justified. Unions have time to raise questions and suggest alternatives to the layoffs but employers and unions need not reach an agreement. Except for some categories of workers, the severance payment is larger than in the case of an individual lay-off. Moreover, firms are obliged to finance outplacement services.

In Belgium we distinguish between two $\mathrm{UI}$ schemes: the temporary $\mathrm{UI}$ scheme and the general scheme. ${ }^{13}$ Currently, only blue-collar workers are eligible to the temporary scheme but employers plead for an extension to white collars. ${ }^{14}$ It allows firms to temporarily lay-off their employees without needing to pay out severance payments since the labour contract remains valid. Firms can make use of this scheme if the economic activity in the firm is temporarily reduced for external reasons, among which economic ones, such as a temporary drop in demand. Workers are entitled to a constant level of unemployment benefits until they are recalled.

Workers with a sufficiently long employment record are entitled to the UB of the general UI scheme if they are involuntarily laid off. ${ }^{15}$ The eligibility period starts after the end of the higher mentioned notice period (even if the latter is not effectively served). The level and profile of the UB depends on the household composition (head of household, single or dependant of the head of household). The level is a fraction of the wage with a floor and a cap. The average net replacement rate is relatively

\footnotetext{
11 For a more precise description, see http://www.rva.fgov.be, http://www.emploi.belgique.be/home.aspx, and http://belgium.angloinfo.com/countries/belgium/contracts.asp.

${ }^{12}$ The worker is protected against arbitrary dismissal though. There also exists a long list of protected workers (see e.g. De Vos and Konings, 2007).

${ }^{13}$ Replacement ratios and/or caps have been revised upwards in January 2009.

${ }^{14}$ As social partners could not agree on a reform, the federal government has agreed upon three measures on April 30, 2009. These measures are in principle limited to the year 2009. The two first ones are respectively a collective and an individual subsidized reduction in working time while the third one introduces temporary lay-offs for blue- and white-collars under some conditions (in particular, a collective agreement).

${ }^{15}$ If the employment record is too short, they are only entitled to a minimum income guarantee provided by the Social Assistance scheme. School-leavers are also entitled to UB after some waiting period. For purposes of simplification, we do not discuss this specific entitlement here (see e.g. Van der Linden, 2007).
} 
low according to international standards: $68 \%$, well below the $73 \%$ average in neighbouring countries. ${ }^{16}$ Heads of households are indefinitely entitled to the same level of UB. The UB for singles and dependants decreases with unemployment duration, but is bounded below by a flat rate UB. Since 2004, job-search effort of long-term unemployed workers is verified and workers may lose their entitlement to UB if this effort is regarded insufficient (see Cockx et al., 2007). UI is provided at the federal level. It's financed through social security contributions that are proportional to the gross wage ${ }^{17}$ Active labour market programmes (ALMP) are mainly provided by the Regions.

\section{What's wrong with the current institutional setting?}

By varying the replacement rate according to the household type, by the imposition of floors and caps, and by providing a number of ad hoc supplementary benefits, ${ }^{18}$ the Belgian UI system has more evolved from an insurance scheme to an unemployment assistance scheme with low replacement rates for high wage workers (but, if white collar, highly protected by the EPL) and high replacement rates for low wage workers. Such a scheme lacks transparency and leads to unemployment traps, especially for low-wage workers. A more transparent scheme would replace the advance notice payments at redundancy (more on this below) by an unemployment compensation that is initially characterised by a unique much higher replacement rate than currently, but that, as to provide the right incentives, would gradually taper off to lower rates the longer one remains unemployed. ${ }^{19}$ Long-term unemployed workers and low-wage workers would be guaranteed a minimum income. Since monetary incentives for minimum income recipients no longer work, incentives for this group should rather take the form of, depending on their effectiveness, the provision of ALMP at reduced costs (or for free, or even subsidised), or by imposing job search requirements and/or by verifying the acceptance of suitable job offers.

Currently, the UI scheme is financed on the basis of contributions that are independent of lay-off behaviour. ${ }^{20}$ This does not at all induce employers to internalize the costs their lay-off decisions impose on society. In contrast, advance notice payments provided for at dismissal from an openended contract make employers accountable for their lay-off behaviour. However, as explained in the first section, this is not an efficient way of insuring workers. Moreover, in Belgium the level of employment protection differs substantially not only according to the seniority in the firm and the wage level, but also to the type of employment contract. Advance notice payments are generally very high for well-paid white-collar workers in open-ended contracts. In contrast, blue-collar workers and all workers who are not (yet) employed in open-ended contracts are relatively weakly protected

\footnotetext{
16 See www.oecd.org/els/social/workincentives (Table on net replacement rates during a 5-year period following unemployment, 2001-2004). Since then, the level of UB has been revised upwards in Belgium.

${ }^{17}$ The contribution rates are respectively $1,46 \%(0,87 \%)$ for employers (employees). An additional contribution rate of $1,69 \%$ is charged to employers occupying at least 10 workers. Finally, there exists a contribution rate to finance a Fund that under specific circumstances pay allowances to redundant workers in case of a firm closing $(0,25 \%$ up to 19 employees, $0,29 \%$ above).

${ }^{18}$ Such as additional child benefits after six months and the benefits to which long-term unemployed workers are entitled by working a small amount of time in specialized agencies ("PWA/ALE").

${ }^{19}$ One may avoid a rapid decrease of the level of UB if, in addition, incentives are provided by a bonus paid out to workers who find employment. However, a constant bonus is then not sufficient. It must decrease with unemployment duration and one should allow it to become negative, i.e. to become a tax, if unemployment lasts long (Hopenhayn and Nicolini, 1997).

${ }^{20}$ A notable exception is, since 2005, the "accountability contribution" paid by firms in the construction sector who temporary lay-off workers during more than 110 days/year. From 2000 to 2002 a similar contribution existed in all sectors for all firms making excessive use of temporary UI scheme. This scheme hasn't been prolonged, however. See e.g. http://www.securex.eu/be/lex-go.nsf/vwNews fr/791FD09EF44C23F5C1257108002E56C1?OpenDocument
} 
according to international standards. Workers in fixed term are relatively well protected before the expiration of the fixed term. However, at the specified term, the employer can fire the worker at no cost. This explains that the bulk of involuntary separations in Belgium is made of workers ending fixed-term contacts: they account for $70 \%$ of the involuntary separations (Delhez et al., 2008) and this in a labour market where fixed term contracts represent less than $9 \%$ of the stock of salaried workers. Since the heterogeneity in EPL between contracts cannot reflect differences in the social cost of dismissal, the differentiation of EPL according to contract type is socially inefficient.

Finally, there is another feature of the Belgian EPL that is matter for concern. The level of advance notice payments for well-paid-white collar workers is not fixed in advance, but needs to be determined by mutual agreement between the worker and the employer. This leads to uncertainty and, possibly judicial costs if no agreement is reached. We believe that efficiency would be enhanced by determining the level of these payments clearly in advance.

\section{Guidelines for the Reform}

1. A unique level of liabilities whatever the type of labour contract. We do not see any theoretical justification for a distinction of the level of the advance notice payments according to the type of worker (blue or white collar) or the type of contract (temporary, open-ended, ...). We therefore plead for establishing a unique level of liabilities that firms are due when laying off any type of worker. Firms could continue to make use of workers occupied by temporary work agencies. However, the contract between these agencies and their workers would be a standard one in terms of liabilities in case of a lay-off. The liabilities would be established at a level that is certainly below the current one for high-paid white-collar workers.

2. A lay-off contribution. The level of firms' liabilities should be proportional to the cost a lay-off imposes on society. Since one can only imperfectly identify dismissals for which individual firms can be held accountable, the lay-off contribution should only be partially related to the cost imposed on society. The contribution should therefore increase with the wage level (since both the level of UB's and the amount of lost taxes increase with wages), with job tenure (since the loss in firm-specific human capital increases with tenure) and with the expected unemployment duration (since the UB payments and the amount of lost taxes increases with unemployment duration).

Since to each lay-off corresponds a fixed social cost (fixed administrative costs related to the payment of UB and the organisation of ALMP), ${ }^{21}$ the contribution should in principle contain a fixed component. However, this would make job creation for brief periods very costly. Consequently, this may hamper the insertion in the labour market for disadvantaged youth, for whom short-lived jobs can be stepping-stones to long-lasting jobs (Cockx, 2008; Cockx and Picchio, 2009). We therefore propose (as Cahuc and Kramarz, 2004) a lay-off contribution that increases at a higher rate during the first period of employment. ${ }^{22}$ Finally, to induce firms to invest both in the prevention of the adverse consequences of lay-off and in outplacement, the lay-off contribution is only due if the worker is not voluntarily employed in another firm (or voluntarily withdraws from the labour market) immediately after dismissal.

\footnotetext{
${ }^{21}$ The fixed psychic costs induced by a lay-off are directly covered by the severance payment to the worker (see point 3 ).

${ }^{22}$ Cahuc and Kramarz (2004) propose a period of 18 months for France.
} 
In practise, we propose a contribution that satisfies only the first two of the above-mentioned principles: a contribution that is proportional to the cumulative past earnings since the moment that the worker was hired in the firm, where the contribution rate would be higher during an initial period (Cahuc and Cramarz, 2004). This form is illustrated in Figure 1. The proposed lay-off contribution does not depend on unemployment duration, since this discourages to recruit disadvantaged workers whose expected unemployment duration is high. The level of the lay-off contribution is then calculated on the basis of the average unemployment duration of a fired worker. Note, however, that, as a consequence, the proposed lay-off contribution makes temporary lay-offs too costly from a social point of view: the social cost of temporary lay-offs is lower, because they are shorter than an unemployment spell on average. This calls therefore for a separate scheme for temporary lay-offs. We will return to this point at the end of this section.

Figure 1: Illustrative profile of the lay-off contribution.

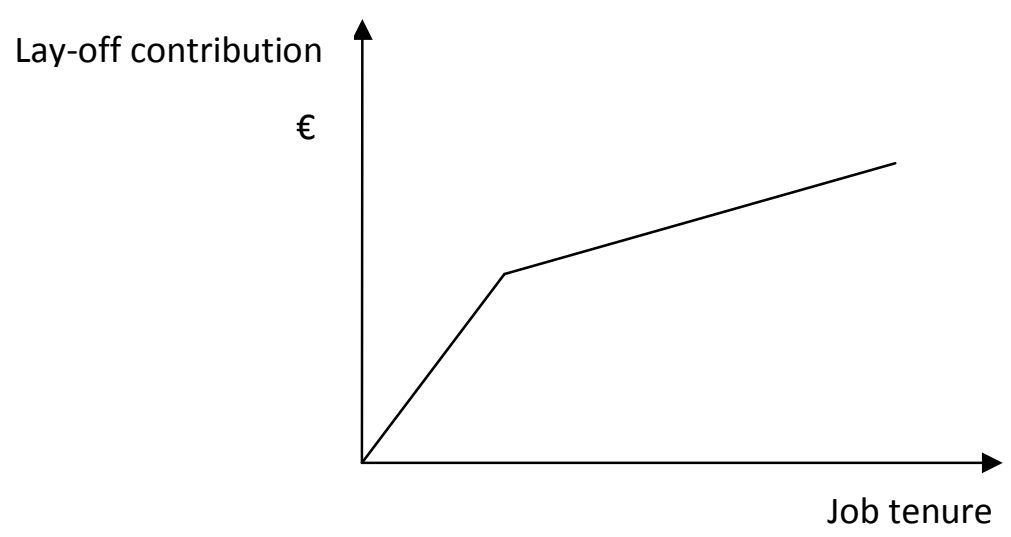

Three refinements should be considered. First, according to the "informativeness principle", the layoff contribution should depend on the difference between the lay-off costs induced by the firm and the average lay-off costs in the economy. This can be done retrospectively on the basis of the lay-off history. Secondly, financially fragile firms risk of going bankrupt when they are made accountable for their dismissals. Smaller firms should therefore pay a lower lay-off contribution. Thirdly, to account for the higher costs a collective dismissal imposes on society, the lay-off contribution should be higher in such a case. The current law ${ }^{23}$ is often criticized for its lack of coherency. There is probably scope for improvement. Still, the idea of giving to unions the possibility to propose alternatives to the collective redundancy should be preserved. However, in accordance with the above arguments, the fact that the compensation currently only takes the form of severance payments to dismissed workers and not a contribution to the UI fund is not satisfactory.

3. A relatively low severance payment. According to the theoretical principles, severance payments should only cover the psychic cost of job loss. These are certainly heterogeneous in the population and this heterogeneity could hardly be taken into account - but on average relatively low for most workers. Since we argued that insurance provides a much more efficient protection against the unemployment risk than severance payments, we plead for transforming the bulk of the advance notice payments into lay-off contributions that finance the UI fund.

${ }^{23}$ The so-called law "Renault". 
4. Improved coverage by the UI. The increased contribution to the UI fund that results from the new lay-off contribution could be used to provide entitlement for workers without a sufficient contribution record and to top up the existing UB for workers who did sufficiently contribute to the $\mathrm{UI}$ fund in the past. For the first group the amount to which they are entitled would be proportional to the lay-off contribution. Since these workers in general have little labour market experience (otherwise they would be entitled to benefits under the current rules), the replacement ratio may be relatively low and, moreover, decreasing as to provide incentives. They would nevertheless be better off than in the current scheme.

For the workers who have a sufficient contribution record, the increased contribution would allow to increase the coverage of $\mathrm{UI}$ by abolishing the current cap and by raising the replacement rate. Incentives would be provided by gradually decreasing this UB supplement with unemployment duration until the current level of UB is attained ${ }^{24}$.

5. An additional funding for ALMP. The additional funds for UI should not only serve to finance the UB supplement. They should partly be assigned to training or employment subsidies to compensate for the loss in firm specific human capital. This is a key difference with the current scheme in which the worker only receives a financial compensation at lay-off and should decide himself/herself upon the amount to invest in active measures. Since the worker does not take into account the social benefit of his re-employment, the worker will certainly under-invest from a social point of view. We believe therefore that the explicit assignment of lay-off contributions to the provision of ALMP will lead to a more efficient functioning of the labour market.

The optimal design of these ALMP is crucial, but complicated and beyond the scope of this contribution. ${ }^{25}$ Moreover, since in Belgium ALMP's are essentially a regional competency, we need to conceive a sensible rule to divide these additional funds between the Regions. We refer the reader to Cockx and Van der Linden (2009) for a more elaborated discussion on this point.

Notice that, since wages are often paid according to seniority rules ${ }^{26}$, lay-off contributions reflecting the social cost of dismissal would be higher for more experienced workers. However, different from the current EPL in the new scheme the lay-off contribution would serve to invest in the activation of the laid-off older worker, through the provision of training and wage subsidies. ${ }^{27}$ This would be much more efficient than the current schemes in which these funds are transferred directly to the worker: the worker assigns only funds to activation according to the private benefits that they generate and thereby under-invests, since the social benefits are much larger.

\footnotetext{
${ }^{24}$ Possibly, one could introduce, additionally, hiring bonuses of which the level decreases with the unemployment duration (see footnote 19).

${ }^{25}$ See Cockx (2000) for a discussion of some of the involved issues and Cockx et al. (2007) for a proposal with regard the monitoring scheme for the unemployed.

${ }^{26}$ Many currently plead to replace the remuneration according to seniority by explicit incentive pay schemes. One should, however, be careful, since explicit performance payment schemes can be shown to be more efficient only if performance can be relatively easily measured. If this is not so, and this is often the case, then payment according to seniority may still be needed to provide the correct incentives (see e.g. Milgrom and Roberts, 1992).

${ }^{27}$ There is no space here for recalling the drawbacks of early-retirement schemes as they are organized in Belgium (see e.g. Sneessens and Van der Linden, 2005).
} 
6. Temporary lay-offs. In the current economic context, temporary lay-offs are extensively used for blue-collar workers and associations of employers call for an extension of the scheme to white collars (see footnote 14). How can this scheme and its potential extension be seen in the light of the above recommendations? If the lay-off contribution is proportional to the social cost induced by the lay-off, in particular with the expected unemployment duration, no distinction would be made between temporary and permanent lay-offs for economic reasons. ${ }^{28}$ However, we proposed the lay-off contribution to be independent of the expected unemployment duration. Being calculated on the basis of the average unemployment duration of a fired worker, this contribution would be too high for temporary lay-offs whose duration is typically shorter. As a consequence, it makes sense to augment the regular UI scheme by one which finances temporary UB's for lay-offs that last less than a predetermined fixed number of days per year. In such a scheme the laid-off worker is still contractually employed and knows in advance when her employer will recall her. Consequently, if a worker is not recalled, the employer still needs to pay the above-mentioned lay-off contribution. In addition, since temporary unemployment imposes a social cost, the employers would need to be made accountable for the extent to which they make use of the system. We would propose a retrospective "experience rating", similar as one of the forms that exists for the funding of UI in the US. ${ }^{29}$ The employers contributions to the scheme would be made proportional to the time that their employees make use of the system: ${ }^{30}$ this guarantees that the scheme would only be used for relatively short unemployment spells. Note that the lack of experience rating (except in the contruction sector ${ }^{31}$ ) is an important drawback of the existing system for blue-collar workers. On the other hand, there is no economic reason to exclude white-collar workers from such a scheme.

7. Individual saving accounts are not the solution. Recently, the Austrian system of individual saving accounts has become a model for reform of the EPL (OECD 2006, European Commission 2006, Sels 2008 and De Vos 2009). In such a scheme the employer contributes a proportion of the wage to an individual account of its employees. Laid-off workers with a seniority above some threshold (3 years in Austria) can choose to withdraw money from this savings account from the moment of dismissal or they may decide to accumulate the savings until a subsequent lay-off or, eventually they may use it as a form of pension fund that allows to top up the pension income after retirement.

There are two main reasons why we oppose to such a scheme. First, since severance payments are financed by contributions before the lay-off occurs, such a scheme violates the first principle of accountability for the social costs it induces by dismissal. Such a scheme will therefore lead to a socially inefficient increase in the number of dismissals in the economy. Second, relying on the principle of individual saving, such a scheme is less efficient than an insurance scheme: workers with insufficient savings are not protected by the scheme and others will save too much for retirement. Proponents of the individual saving accounts would counter argue that an insurance scheme provides disincentives for work, which an individual savings account does not. However, a decreasing

\footnotetext{
${ }^{28}$ Temporary lay-offs for other reasons can be maintained and even generalized to white collar workers, since these other reasons (climatic conditions, mechanical failure, a fire,...) are to a large extent out of the control of the firm and easily verified by a third party.

${ }^{29}$ There does not exist one scheme of experience rating in the US. Each state can decide upon a different scheme. In the Appendix we include a succinct description extracted from an OECD (2004) study. See also e.g. Fath and Fuest (2005) for a more detailed description.

${ }^{30}$ Note that a refinement consists in decreasing (increasing) the employer's contribution as the business cycle goes down (up).

${ }^{31}$ See footnote 20 .
} 
profile of unemployment benefits and/or monitoring and counselling schemes in UI can cope with these disincentives without losing the main benefits of an insurance scheme.

\section{Conclusion}

Economists see job destruction as part of a process of innovation and growth (hence, the expression "creative destruction"). For most workers however, a lay-off is a disaster and an injustice. The reform proposed here takes both points of view into account. It renders both employers and employees more conscious of their responsibilities with respect to society as a whole.

In a nutshell, we propose to transform the bulk of the advance notice payments currently paid to the laid-off worker by a unique lay-off contribution paid to the Unemployment Agency ${ }^{32}$, independently of the type of worker (blue or white-collar) and type of contract (temporary or openended). A relatively small severance payment is due to cover the psychic cost related to dismissal. In order to make the employer accountable for the costs he imposes on society, the lay-off contribution should be made proportional to the cumulative past earnings since the moment that the worker was hired in the firm. This contribution would be used not only to finance a supplement to the current unemployment benefits, but also, as to make the worker more accountable, to finance active labour market policies for the unemployed. Aside of this scheme, it makes sense to generalise the current scheme of temporary unemployment benefits for blue-collar workers to white-collar workers, but only to the extent that one introduces experience rating in the funding, so that again the employers are made accountable for the social costs that they induce by these temporary lay-offs.

It is clear that much more work is needed to transform these principles into a directly implementable reform and to estimate its social value. This is a next step.

\section{Appendix}

\section{Box 2.5. The system of Experience Rating in the United States ${ }^{33}$}

The United States is the only OECD country that makes widespread use of a tax on layoffs used to finance UI payments to dismissed workers. Employers' social security contributions are partially "experience rated", i.e. they are calculated partly on the basis of the layoff activity of the firm: a firm's tax rate is determined by individual States based on the UI benefits paid to employees it has recently laid off. There is considerable variation across States in terms of how tax rates are precisely assessed. Each year the UI funds in each State fix a set of contribution rates based on the situation of their accounts. As a result, rates of employers' contributions vary widely across States, both in terms of the minimum and maximum contribution rates and within these two boundaries. In fact, the only federal rule concerns the maximum contribution rate, which has to be at least equal to $5.4 \%$.

\footnotetext{
${ }^{32}$ Since in Belgium the UA is partly regionalized, this new funding should be partly shared among the Regional institutions. This is discussed in Cockx and Van der Linden (2009).

${ }^{33}$ This description is extracted from $\operatorname{OECD}(2004$, p. 94)
} 
To determine what contribution rate should apply to each firm, the vast majority of States follow either a "benefit ratio" approach or a "reserve ratio" method (see Fougère and Margolis, 2000). Under the "benefit ratio" system, firms pay taxes in proportion to the ratio of: 1) benefits charged to their account (paid to its laid-off employees); to 2) taxable wages, both averaged over the preceding three to five years. Under the "reserve ratio" system, firms pay taxes that are a function of the ratio of: 1) their reserves, that is past taxes less benefit payments accumulated over the entire history of the firm; to 2) their taxable payroll averaged over the preceding three years. Each approach yields a measure of how much a firm's laid-off employees have drawn on the UI system over the previous three years. As this amount increases, the firm's tax rate rises.

Over the long life of this system, the contribution rate seems to have followed the economic cycle with some lag. This lag originates from the fact that $\mathrm{UI}$ funds fix their set of rates on the basis of the state of their accounts of the previous years. At the beginning of a recession, disbursements from UI funds increase while contribution rates remain unchanged. This continues until the UI funds balances worsen and a new, stricter set of contribution rates is introduced. When the balance of UI funds becomes negative, the government provides a loan. Reimbursing this loan may require contribution rates to remain high for a certain period after the end of the recession.

In all States, experience rating is only partial in that taxes charged to a firm do not rise on a dollarfor-dollar basis with benefits drawn by that firm's laid-off workers. The lack of complete experience rating occurs for three reasons. First, a firm's decision to lay off employees has no impact on its tax payments when it is either already at the maximum tax rate or below the minimum rate. Second, for firms that are between these two extremes, tax rate increases due to a change in the reserve/benefit ratio are typically insufficient to meet the full cost of the benefits resulting from layoffs. Third, in certain States, some UI benefits are not charged to the firm: for example, those paid to short-tenure employees, students who have returned to school, or individuals whose employers have gone bankrupt. In fact, in 2002, employers covered only partially the expense caused by their layoff behaviour, with the remaining implicitly funded by general taxation. Employers coverage varies considerably across States, ranging from $72 \%$ in New Hampshire to $14 \%$ in Georgia, and does not seem to depend much on the system used to calculate contribution rates.*

* Source: www.workforcesecurity.doleta.gov/dmstree/uipl/uipl2k3/uip/ 2603a1.htm.

\section{References}

Blanchard, O. and J. Tirole (2003), "Protection pour l'Emploi et Procédures de Licenciement ", Rapport pour le Conseil d'Analyse Economique, Paris : La Documentation française.

Blanchard, O., and J. Tirole (2004), "Redesigning the Employment Protection System", De Economist, $152(1)$, pp. 1-20.

Blanchard, O. and J. Tirole (2008), "The joint design of unemployment insurance and employment protection. A first pass", The Journal of the European Economic Association, 6 (1), pp. 45-77. 
Cahuc, P. and F. Kramarz (2004), De la Précarité à la Mobilité : vers une Sécurité sociale professionnelle, Rapport au Ministre d'Etat, Ministre de l'Economie, des Finances et de l'Industrie et au Ministre de l'Emploi, du Travail et de la Cohésion sociale, Paris.

Cockx B. (2000), "The design of active labour market policies: Building in effective incentives", International Labour Review, 139 (4),457-480.

Cockx, B. (2008), "Is een kortstondige job voor jongeren zonder werkervaring een springplank naar een duurzame baan?", Over.Werk, 18, 3-4.

Cockx B., M. Dejemeppe and B. Van der Linden (2007), "Bevordert het Plan voor de begeleiding en opvolging van werklozen de overgang naar werk?", Over.Werk, 1, 85-88. Also available as Regards économiques, 49. http://www.uclouvain.be/regardseconomiques

Cockx, B. and M. Picchio (2009), "Are Short-Lived Jobs Stepping Stones to Long-Lasting Jobs?", Working paper 2009-560, Faculty of Economics and Business Administration, Ghent University, IRES DP 2009-04, UCLouvain, IZA 4007, CESifo 2569.

Cockx, B., H. Sneessens, B. Van der Linden, A. Batyra, G. Cardullo, M. Dejemeppe, M. Denni, C. Göbel and E. Moreno (2005a), Evaluations micro et macroéconomiques des allégements de la (para)fiscalité en Belgique, Report ordered by the National ministry of Science, Gent : Academia Press.

Cockx, B., H. Sneessens and B. Van der Linden (2005b), "Allégement des cotisations patronales à la sécurité sociale : pourquoi, pour qui et comment ?", Revue belge de Sécurité sociale, $\mathrm{n}^{\circ} 4, \mathrm{pp}$. 583598.

Cockx, B. and B. Van der Linden (2009), "Decentralisation of Labour Market Policies May Matter, but Other Reforms Matter More", E-book, www.rethinkingbelgium.eu/rebel-initiative-ebooks

Delhez P., P. Heuse, Y. Saks and H. Zimmer (2008) "Le bilan social 2007"; Revue économique, décembre, $105-146$.

De Vos, M. (2009), "Pleidooi voor een nieuw ontslagrecht", De Standaard, 23 maart.

De Vos, M., en J. Konings (2007), Van baanzekerheid naar werkzekerheid op de Belgische arbeidsmarkt, Itinera Institute, Intersentia, Antwerpen - Oxford.

European Commission (2006), Employment in Europe 2006.

Fath J. and C. Fuest (2005), "Experience Rating of Unemployment in the US: A Model for Europe?", CESifo DICE Report, Journal for Institutional Comparison, 2, pp. 45-50.

Fougère D. et D. Margolis (2000) : «Moduler les cotisations employeurs à l'assurance chômage : les expériences de bonus-malus aux États-Unis ", Revue Française d’Économie, n² 2, pp. 3-76.

Hopenhayn, H. A. and J. P. Nicolini (1997), "Optimal Unemployment Insurance”, Journal of Political Economy, 105(2), 412-438.

Milgrom, P. and J. Roberts (1992), Economics, Organization and Management, London: Prentice Hall International Editions. 
OECD $(2004,2006)$, Employment Outlook, Paris.

Pissarides, C. (2001), “Employment Protection”, Labour Economics, 8, 131-159.

Sels L. (2008), "Beschermde mobiliteit of beschermen tegen mobiliteit? Recepten voor een (te?) stabiele arbeidsmarkt.", Over.werk, 2, 54- 70.

Sneessens H. and B. Van der Linden (2005) "Les préretraites sont-elles une méthode efficace de gestion des carrières et de l'emploi ?", Over.Werk, 4, 99 - 106. Also available as Regards économiques, 33. http://www.uclouvain.be/regardseconomiques

Van der Linden B. (2005), "Une proposition de renforcement des allégements de charges sociales patronales sur les bas salaires", Regards économiques, 34.

http://www.uclouvain.be/regardseconomiques

Van der Linden B. (2007), "Un regard universitaire francophone sur le rapport Des emplois pour les jeunes", Over.werk, 2, 49-55. Also available as Regards économiques, 56.

http://www.uclouvain.be/regardseconomiques 